\title{
Use of remote sensing for detecting and mapping leafy spurge (Euphorbia esula) ${ }^{1}$
}

\author{
JAMES H. EVERITT, GERALD L. ANDERSON, DAVID E. ESCOBAR, MICHAEL \\ R. DAVIS, NEAL R. SPENCER, and ROGER J. ANDRASCIK \\ Range Sci., Ecologist, Remote Sensing Spec., and Airplane Pilot, Remote Sensing Research Unit, Agric. Res. Serv., \\ U.S. Dep. Agric., 2413 E. Hwy 83, Weslaco, TX 78596; Entomologist, Agric. Res. Serv., U.S. Dep. Agric., P.O. Box \\ 1109, Sidney, MT 59270; and Resource Manage. Spec., National Park Service, U.S. Dep. Inter., P.O. Box 7, Medora, \\ ND 58645 .
}

\begin{abstract}
:
Leafy spurge is a troublesome, exotic weed in the northern Great Plains of the United States. Leafy spurge produces showy yellow bracts during June that give this weed a conspicuous appearance. A study was conducted to determine the feasibility of using remote sensing techniques to detect leafy spurge in this phenological stage. Study sites were located in North Dakota and Montana. Plant canopy reflectance measurements showed that leafy spurge had higher visible $(0.63$ - to $0.69-\mu \mathrm{m})$ reflectance than several associated plant species. The conspicuous yellow bracts of leafy spurge gave it distinct yellow-green and pink images on conventional color and color-infrared aerial photographs, respectively. Leafy spurge also could be distinguished on conventional color video imagery where it had a golden yellow image response. Quantitative data obtained from digitized video images showed that leafy spurge had statistically different digital values from those of associated vegetation and soil. Computer analyses of video images showed that light reflected from leafy spurge populations could be quantified from associated vegetation. This technique permits area estimates of leafy spurge populations. Large format conventional color photographs of Theodore Roosevelt National Park near Medora, ND were digitized and integrated with a geographic information system to produce a map of leafy spurge populations within the park that can be useful to monitor the spread or decline of leafy spurge.
\end{abstract}

\section{Nomenclature:}

Leafy spurge, Euphorbia esula L., \#² EPHES

\footnotetext{
${ }^{1}$ Received for publication Jan. 3, 1995 and in revised form June 5, 1995.
} 


\section{Additional index words:}

Color-infrared photography, conventional color photography, conventional color video imagery, geographic information system, global positioning system, light reflectance.

\section{Introduction}

Leafy spurge is a deep rooted, perennial weed with erect stems 40 to $80 \mathrm{~cm}$ tall (37), which reproduces by both vegetative regrowth and by producing large quantities of seeds. Leafy spurge, a native of Eurasia, was first reported in the United States in Massachusetts in 1827 (28). This weed is now most abundant in the Northern Great Plains of the United States and the Prairie Provinces of Canada (31). It often forms dense stands on rangelands and pastures, displacing useful forage plants and restricting cattle grazing.

Various control methods have been employed on leafy spurge. Chemical control has been used extensively on the weed $(21,24)$. However, long term control with chemicals has generally proven ineffective and therefore expensive particularly because of the extensive acreage infested by this troublesome pest (1). Sheep grazing has been used to reduce the density and limit the spread of leafy spurge, but it will not eradicate the weed $(18,23)$. Other biological control methods with pathogens $(30)$ and insects $(4,31)$ are also being used on leafy spurge, but these methods will not eradicate this weed. Good control has been obtained on small areas near release sites of the Chinese leaf beetle (Aphthona nigriscutis Foudras); however, this research will take time to assess.

Determining the extent of weed populations on rangelands is difficult because of the generally great expanse and inaccessibility of these areas. The value of remote sensing techniques for rangeland assessment is well established (40). Remote sensing techniques offer the advantage of rapid acquisition of data with generally short turnaround time and a procedure that is considerably less costly than ground surveys $(9,40)$.

Plant canopy light reflectance measurements have been used to characterize the spectral characteristics of plant species and aerial photography and videography have proven useful for detecting plant species on rangelands $(9,12,15,19)$. Many rangeland plant species are distinguishable on aerial imagery when in specific phenological stages (10, 17). Leafy spurge produces showy yellow bracts in late May or early June giving the plant a conspicuous appearance (22). It is surmised that leafy spurge might be distinguishable on aerial imagery in this phenological stage.

Myhre (26), in a preliminary study, indicated that aerial photography might be a useful tool to detect and map leafy spurge infestations. However, no conclusive findings were reported from this research. Elliston and Miller (8) used aerial videography to detect

\footnotetext{
${ }^{2}$ Letters following this symbol are WSSA-approved computer codes from Composite List of Weeds, Revised 1989. Available from WSSA, 1508 West University Ave., Champaign, IL 61820-3133.
} 
leafy spurge infestations on Wyoming rangelands. Videographic images were subjected to image processing techniques to show locations of heavy, light, and no infestation of leafy spurge with a high degree of accuracy.

Remotely sensed data have been integrated with geographic information system $(\mathrm{GIS})^{3}$ technology for a variety of natural resource applications $(3,7,20,27,33)$, including mapping the distribution of noxious weeds $(2,6,14,29)$. The merging of remote sensing and GIS technologies can be useful to assess the extent of infestations, develop management strategies, and evaluate the effects of control measures on noxious plant populations.

The objectives of this study were: (a) to establish the plant canopy light reflectance characteristics of leafy spurge; (b) to evaluate the use of aerial photography and videography for distinguishing leafy spurge infestations on North Dakota and Montana rangelands; and (c) to demonstrate the integration of remotely sensed data in a GIS for mapping leafy spurge populations.

\section{Materials and methods}

This study was conducted in rangeland areas of North Dakota and Montana. The principal study site was the 18,680 ha south unit of the Theodore Roosevelt National Park, near Medora, ND, in the southwestern part of the state. Additional study sites were located near Lewistown, in central Montana, and near Bozeman in south-central Montana. These sites were selected as study areas because leafy spurge is a major weed at these locations. The Lewistown study site was located within a 16 by $16-\mathrm{km}$ rangeland area and was part of a USDA-ARS research project on biological control of leafy spurge. The Bozeman site was a 2 by $2-\mathrm{km}$ rangeland area.

Multiple study sites were selected to determine if remote sensing techniques could be used to distinguish leafy spurge populations at widely separated locations. Plant canopy and soil reflectance measurements, aerial photographs, and video imagery, along with ground truth observations were made in this study. Reflectance measurements were made to establish the spectral characteristics of leafy spurge, associated plant species, and soil, and to help interpret the imagery. Ground observations were made to verify the aerial imagery.

Plant and soil reflectance measurements were made near Medora and Bozeman on June 17 and 19, 1993, respectively. Measurements were made on 10 randomly selected plant canopies of each species or species mixture and soil surfaces on each date with a portable hand-held radiometer ${ }^{4}(39)$.

Reflectance measurements were made at two sites: Medora and Bozeman. Both visible red (0.63- to $0.69-\mu \mathrm{m})$ and near-infrared (NIR) ${ }^{3}(0.76-$ to $0.90-\mu \mathrm{m})$ reflectance measurements were made using a sensor with a $15^{\circ}$ field of-view. Reflectance measurements

\footnotetext{
${ }^{3}$ Abbreviations: CIR, color-infrared; GIS, geographic information system; GPS, global positioning system; NIR, nearinfrared.

${ }^{4}$ NASAGSFCMARK-II radiometer, NASAGoddard, Greenbelt, MD 20770.
}

Page 3 of 15 
conducted at the Medora site were made on leafy spurge, yellow sweetclover [Melilotus officinalis (L.) Lam. \# MEUOF], pinnate tansymustard [Descurainia pinnata (Walt.) Britt. \# DESPI], smooth brome (Bromus inermis Leyss. \# BROIN), crested wheatgrass [Agropyron desertorum (Tisch. ex Link) Shult.], western snowberry (Symphoricarpos occidentalis Hook. \# SYPOC), silver sagebrush (Artemisia cana Pursh.), creeping juniper (Juniperus horizontalis Moench), Rocky Mountain juniper (Juniperus scopulorum Sarg.), mixed herbaceous species, bare soil, and clay rock. The predominant mixed herbaceous species were purple coneflower (Echinacea angustifolia DC.), tumbling mustard (Sisymbrium altissimum L. \# SSAYL), hedge bindweed (Calystegia sepium (L.) R. Br. \# CAGSE), pinnate tansymustard, smooth brome, and crested wheatgrass.

Reflectance measurements at the Bozeman site were made on leafy spurge, yellow sweetclover, western wild rose (Rosa woodsii Lindl.), big sagebrush (Artemisia tridentata Nutt. \# ARTTR), mixed herbaceous species, and bare soil/rocks. The dominant mixed herbaceous species included white sweetclover (Melilotus alba Medicus \# MEUAL), Canada wild-rye (Elymus canadensis L.), and crested wheatgrass. Yellow sweetclover and pinnate tansymustard were in light and heavy flowering, respectively, at Medora; whereas, yellow sweetclover was in moderate to heavy flowering at Bozeman. Reflectance measurements were made between 1100 and 1500 hours mountain standard time. Radiometric measurements were corrected to reflectance at a common solar irradiance reference condition (32).

Conventional color $(0.40-$ to $0.70-\mu \mathrm{m})$ and color-infrared(CIR $)^{3}(0.50-$ to $0.90-\mu \mathrm{m})$ films ${ }^{5}$ were used for aerial photographs. Conventional color film has visible light sensitivity, but CIR film has both visible $(0.50-$ to $0.75-\mu \mathrm{m})$ and NIR $(0.76-$ to $0.90-\mu \mathrm{m})$ light sensitivity. Photographs were taken with a large format camera ${ }^{6}(23$ by $23-\mathrm{cm})$ and small format twin cameras ${ }^{7}(5.7$ by $5.7-\mathrm{cm})$. Only conventional color film was used in the large format camera. It had a $305-\mathrm{mm}$ lens. The aperture setting was f11 at 1/250 s. The large format camera was used to obtain imagery of all study sites near Lewistown and Medora because of its wide ground coverage. Several sites known to be infested with leafy spurge were photographed near Lewistown on June 18, 1993 at a scale of 1:4000 (0.12 m resolution). The entire south unit of Theodore Roosevelt National Park near Medora was photographed on June 19,1993 at a scale of $1: 10,000$ ( $0.3 \mathrm{~m}$ resolution). When the twin cameras were used, one was loaded with conventional color film and the other with CIR film. The twin cameras were used to compare the two types of film for detecting leafy spurge. The camera containing CIR film was equipped with an orange (minus blue) filter. The cameras had an aperture setting of $\mathrm{f} 8$ at $1 / 500 \mathrm{~s}$. Both cameras were equipped with $80-\mathrm{mm}$. lenses. The twin cameras were used to obtain photographs of eight locations known to be infested with leafy spurge at the Lewistown study area on June 18, 1993 at a scale of 1:15,000 ( $0.5 \mathrm{~m}$ resolution).

\footnotetext{
${ }^{5}$ Kodak Aerochrome types 2448 (conventional color) and 2443 (color-infrared), Eastman Kodak Co., Rochester, NY 14601. Mention of a company name or trademark is for the readers' benefit and does not constitute endorsement of a particular product by the U.S. Dep. Agric. Over others that may be commercially available.

${ }^{6}$ Fairchild type K-37, Fairchild Camera and Instrument Corp., Jamaica, NY 11431.

${ }^{7}$ Hasselflad Model 500 camera, Victor Hasselblad, Inc., Fairfield, NJ 07006.
}

Page 4 of 15 
Aerial video imagery was obtained of leafy spurge to determine its potential for detecting this weed. Video imagery was taken with a conventional color single-unit video camera $^{8}$. The camera had a charge-coupled device sensor $(0.40-$ to $0.70-\mu \mathrm{m})$ that was sensitive in the visible blue $(0.40$ - to $0.50-\mu \mathrm{m})$, green $(0.50-$ to $0.60-\mu \mathrm{m})$ and red $(0.60-$ to $0.70-\mu \mathrm{m})$ spectral wavebands. Imagery was recorded on a super-VHS portable video recorder $^{9}(2.5-\mathrm{cm}$ format). The camera lens was set at $15-\mathrm{mm}$ focal length.

Video recordings were obtained of eight known populations of leafy spurge at the Lewistown study area on June 18, 1993 and of six known populations of leafy spurge along the Little Missouri River within Theodore Roosevelt National Park (Medora) on June 19, 1993. The Medora imagery was acquired at altitudes of 2600 and $3000 \mathrm{~m}$ above ground level, with width of ground coverages of 1.5 and $1.7 \mathrm{~m}$, and horizontal ground pixel sizes of 2.8 and $3.2 \mathrm{~m}$, respectively. Imagery taken at Lewistown was obtained at $1200 \mathrm{~m}$ above ground level $(0.7 \mathrm{~km}$ width of ground coverage) and had a horizontal ground pixel size of $1.3 \mathrm{~m}$. All imagery was obtained with a fixed-wing aircraft between 930 and 1500 hours mountain standard time.

A global positioning system ${ }^{10}$ (GPS) ${ }^{3}$ was integrated with the video system to demonstrate the use of the two technologies. The GPS continuously calculates and displays the flight direction (bearing), altitude, time, ground speed, and latitude/longitude coordinates of the aircraft location above sea level. An interphaser ${ }^{11}$ was, used to transfer and record the GPS information on the last two lines of the video images. The accuracy of the GPS latitude/longitude data was approximately $\pm 100 \mathrm{~m}$ from the center coordinates of each video image.

Video images of leafy spurge obtained near Medora and Lewistown were digitized with a 486 PC-clone computer having a 512 by 512 pixel image digitizing board and image processing software ${ }^{12}$. Two images from each location were used in the study. Images were entered into the computer using a super-VHS cassette recorder player. Leafy spurge classifications were conducted on one image from each location using the "color segment" routine ${ }^{12}$. This technique separated objects or features from the background based on color attributes.

The quantification of leafy spurge was conducted with the "area of interest" histogram function ${ }^{12}$ which estimated the percentage of total pixels that represented the weed in the images. Digital color values were obtained from the red, green, and blue bands from all four video scenes using the "point analysis" function ${ }^{12}$. Ten random one-pixel data points were extracted from leafy spurge and two to three associated land cover types in each scene.

A photo interpretive procedure was used on photographic transparencies of the same two video images (Medora and Lewistown) subjected to the computer classification tech-

\footnotetext{
${ }^{8}$ Cohu Model 1815, cohu Inc., San Diego, CA 92123.

${ }^{9}$ Panasonic model AG-7400 Super-VHS Recorder, Panasonic Industrial Co., Secaucus NJ 07094

${ }^{10}$ Trimble Transpak II Global Positioning System, Trimble Navigation Ltd., Sunnyvalle, CA 94086.

${ }^{11}$ Compix Model LP-701, Compix Inc., Tualatin, OR 97062.

${ }^{12}$ Image-Pro Plus, Media Cybernetics, Silver Springs, MD 20910.
}

Page 5 of 15 
nique to compare differences in percent quantification between techniques. The transparencies were obtained by photographing each video image from a TV monitor. A "mask" was made of each transparency by tracing areas thought to be occupied by leafy spurge onto a transparent paper overlay of the transparency (11). These areas were coded black and the remainder of the mask was left white. The masked tracings were scanned using a line scanner ${ }^{13}$ and subjected to the "area of interest" histogram function ${ }^{12}$ to quantify the total area of leafy spurge in each respective tracing.

The large format aerial photography was used to map the distribution of leafy spurge within Theodore Roosevelt National Park. The mapping process included several steps. First, all aerial photographs were examined to determine whether leafy spurge was visible within the scene. Photographs containing leafy spurge were covered with a clear vellum to protect the original print and the perimeters of the leafy spurge populations were drawn on the overlay.

Tie points that georeferenced features on the photograph with coordinates from USGS 7.5-min base maps were also identified and marked on each photograph. Terrain features such as butte tops, clay outcroppings, and stream intersections were used as tie points because each photograph contained few identifiable standard map features. The USGS 7.5-min orthophoto quadrangle maps that were available for the park enabled this procedure. Coordinates for the tie points were obtained from the orthophoto maps by digitizing each position and recording it in a GIS. The corresponding tie points on the photographs and the perimeter of each leafy spurge population also were digitized and recorded in the GIS.

The registration procedure used the common tie points on the photographs and orthophoto quadrangle maps to register the leafy spurge polygons to a standard North American Datum (NAD), 1983, Universal Transverse Mercator (UTM), Zone 13, coordinate system. A minimum of 10 tie points, scattered across the image, were selected on each aerial photograph. Standard map features such as roads, trails, hydrography, and the park boundary were digitized from a USGS, 1:24,000 scale topographic map converted to a NAD-1983 coordinate base and combined with the leafy spurge polygons in a raster GIS.

Ground truth surveys were made at the majority of sites where imagery was obtained. The sites were not chosen randomly, but rather were visited to confirm the presence or absence of leafy spurge after viewing the imagery. No quantitative analysis was performed on the ground truth. Observational data recorded were plant species, density, and cover. Ground reconnaissance was made on all sites where the small format film and video imagery was acquired. Leafy spurge sites selected from the large format photography of the entire south unit of Theodore Roosevelt National Park were plotted on a park map to facilitate ground surveys. Aerial conventional color photographic prints were also used in the ground surveys to assist in locating leafy spurge populations. Several sites were inaccessible because of the rugged terrain and had to be viewed from low altitude aircraft. Ground level photographs were taken to help interpret aerial photographs and video images. Overhead photographs were taken of plant canopies and soil surfaces measured with the radiometer to help interpret reflectance data.

${ }^{13}$ Umax Model VC630, Image-In, Inc., Minneapolis, MN 55420.

Page 6 of 15 
Visible and NIR reflectance data and digital color value data obtained from the video images were analyzed using analysis of variance techniques. Duncan's multiple range test was used to test significance among means at the 0.05 probability level (36).

\section{Results and discussion}

Reflectance measurements. Leafy spurge at Medora had lower visible reflectance than bare soil and clay rock and higher visible reflectance than nine other associated plant species and mixtures of species (Table 1). The distinct visible reflectance of leafy spurge was attributed to its bright yellow-green bracts. The upper canopy of leafy spurge, which included a mass of bracts, absorbed less visible red light than the other species and mixtures which were primarily green foliage (17). Although yellow sweetclover and pinnate tansymustard were in light and heavy flowering, respectively, their light yellow flowers apparently did not contribute greatly to their visible reflectance. Pinnate tansymustard flowers are small and do not form a mass, thus its visible reflectance is primarily influenced by the leaves and stems. The NIR reflectance of leafy spurge did not differ from that, of pinnate tansymustard and western snowberry. Near-infrared reflectance in vegetation is highly correlated with plant density $(13,38)$.

An overhead view of the plant species and mixtures showed that leafy spurge, pinnate tansymustard, and western snowberry had similar vegetative densities and that their canopies had greater vegetative densities and less gaps (sun flecks) than the other associated species and mixtures. The higher visible and low to moderate NIR reflectance of the soils agrees with other research findings $(5,9,35)$.

Table 1. Mean canopy reflectance of leafy spurge, associated plant species and mixtures of species, and soil for the visible (red) and near-infrared bands at two study sites. Reflectance measurements were made near Medora, ND on June 17, 1993, and Bozeman, MT on June 19, 1993.

\begin{tabular}{llll} 
& & \multicolumn{2}{l}{ Canopy reflectance Values ${ }^{\mathrm{a}}$} \\
\cline { 3 - 4 } Site & Plant species, mixture, or soil & $0.63-0.69 \mu \mathrm{m}$ & $0.76-0.90 \mu \mathrm{m}$ \\
\multirow{3}{*}{ Medora, ND } & $12.4 \mathrm{a}$ & $16.9 \mathrm{de}$ \\
& Bare soil & $10.3 \mathrm{~b}$ & $17.4 \mathrm{de}$ \\
& Clay rock & $3.7 \mathrm{c}$ & $40.3 \mathrm{ab}$ \\
& Leafy spurge & $2.4 \mathrm{~d}$ & $19.0 \mathrm{~d}$ \\
& Silver sagebrush & $1.7 \mathrm{~d}$ & $24.9 \mathrm{c}$ \\
& Yellow sweetclover-light flowering & $1.6 \mathrm{~d}$ & $18.3 \mathrm{de}$ \\
& Rocky Mountain juniper & $1.5 \mathrm{~d}$ & $20.5 \mathrm{~d}$ \\
& Mixed herbaceous species & $1.3 \mathrm{~d}$ & $15.0 \mathrm{e}$ \\
& Smooth brome & $1.3 \mathrm{~d}$ & $18.4 \mathrm{de}$ \\
& Crested wheatgrass & $1.1 \mathrm{~d}$ & $17.2 \mathrm{de}$ \\
& Creeping juniper & $1.1 \mathrm{~d}$ & $43.4 \mathrm{a}$ \\
& Pinnate tansymustard-heavy flowering & $1.0 \mathrm{~d}$ & $39.4 \mathrm{~b}$ \\
& Western snowberry & $8.3 \mathrm{a}$ & $12.7 \mathrm{~d}$ \\
Bare soil/rocks & $3.8 \mathrm{~b}$ & $41.6 \mathrm{a}$ \\
& Leafy spurge & $2.4 \mathrm{c}$ & $41.2 \mathrm{a}$ \\
& Yellow sweetclover-moderate to heavy flowering & $1.9 \mathrm{~cd}$ & $14.4 \mathrm{~d}$ \\
& Big sagebrush & $1.4 \mathrm{~d}$ & $35.9 \mathrm{~b}$ \\
& Western wild rose & $1.3 \mathrm{~d}$ & $29.6 \mathrm{c}$ \\
\hline
\end{tabular}

${ }^{a}$ Values within a column at each site/date followed by the same letter do not differ significantly at the 0.05 probability level according to Duncan's multiple range test. 
Reflectance measurements of leafy spurge, associated plant species, and soil at the Bozeman site followed the same general pattern as was shown at Medora (Table 1). Leafy spurge had lower visible reflectance than bare soil/rocks and higher visible reflectance than yellow sweetclover, big sagebrush, western wild rose, and mixed herbaceous species.

Yellow sweetclover was in moderate to heavy flowering, but its yellow flowers had lower visible reflectance than the yellow-green bracts of leafy spurge (Table 1). At the NIR wavelength, the reflectance of leafy spurge did not differ from that of yellow sweetclover. Overhead views of their canopies showed that both species had similar vegetative densities. These findings indicate that the bright yellow-green bracts of leafy spurge give it distinct visible reflectance.

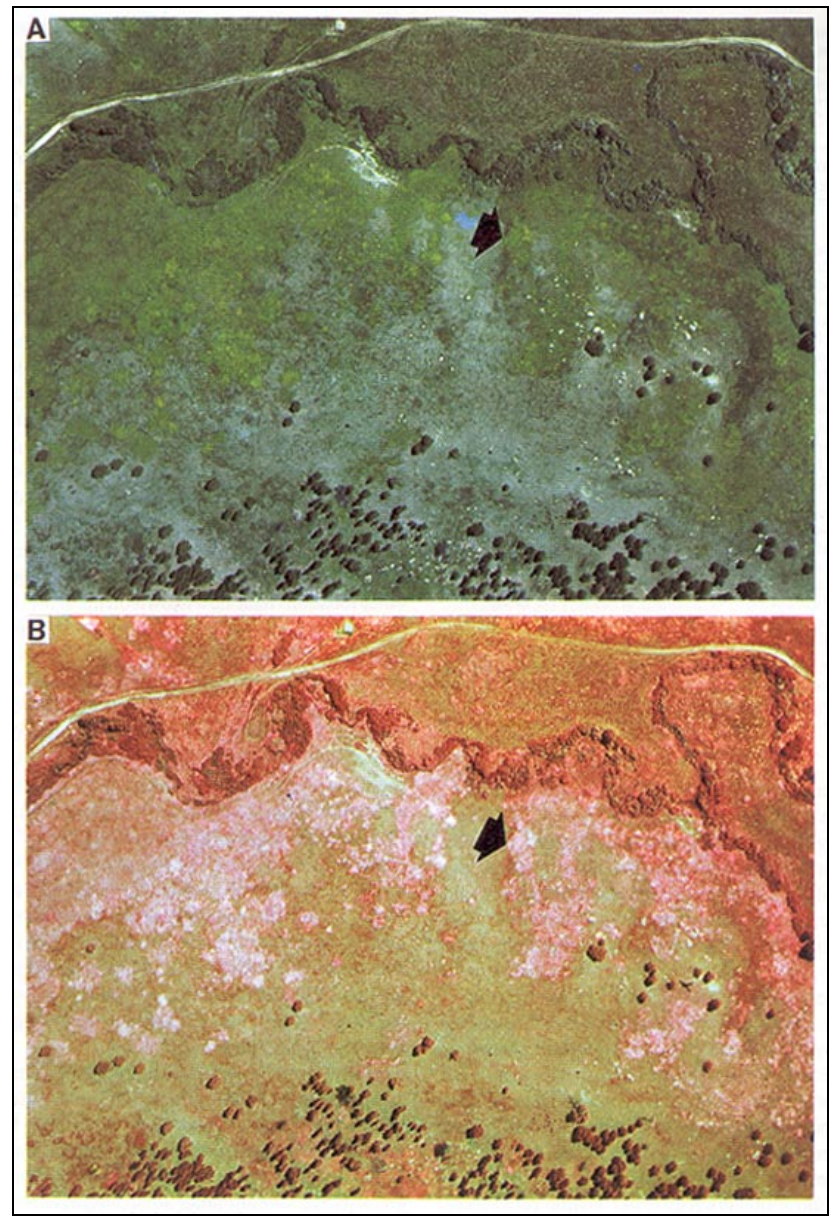

Figure 1. Conventional color (A) and color-infrared (B) photographs of a leafy spurge infestation near Lewistown, MT The photos were obtained on June 18, 1993. Both prints are $6 \times$ enlargements of portions of $70-\mathrm{mm}$ photographs taken at an original scale of 1:15 000. Arrows on the prints point to the yellow-green and pink image responses of leafy spurge on each respective film type.

Aerial photography. Leafy spurge has a conspicuous yellow-green image response in the conventional color photograph that can be easily distinguished from the dark graygreen image of mixed brush, light gray-green tone of mixed herbaceous species, light gray response of sparsely vegetated areas, and whitish response of bare soil and rocks (Figure 1A). The denser stands of leafy spurge have a bright yellow-green color, whereas the sparse stands have a dull yellow-green response. Leafy spurge in the CIR photograph 
has a pink image response that can be readily separated from the various red, dark magenta, and reddish-brown image responses of mixed brush, dull magenta to magenta response of mixed herbaceous species, light tan tone of sparsely vegetated areas, and whitish response of bare soil and rocks (Figure $1 \mathrm{~B}$ ).

Leafy spurge had a similar image response in additional conventional color and CIR photographs acquired at seven other locations near Lewistown on the same date and could be easily distinguished in all photos. Leafy spurge also had a similar yellow-green image in additional large format conventional color photographs obtained near Medora, ND, on June 19, 1993 that could be differentiated from associated vegetation and soil. The distinct image response of leafy spurge in both conventional color and CIR photographs was primarily attributed to its higher visible light reflectance than that of the other plant species (Table 1). However, the high NIR light reflectance of leafy spurge contributed to its image response in the CIR photography, as CIR film has both visible and NIR light sensitivity.

A qualitative assessment of the conventional color and CIR photography obtained near Lewistown showed that both types of film did a good job in distinguishing leafy spurge. This was confirmed by intense ground surveys of the study sites. Thus, both films were judged equal for detecting leafy spurge infestations.

Aerial videography. Conventional color video images of leafy spurge infestations near Medora and Lewistown are shown in Figures 2A and 2B, respectively. Leafy spurge has a distinct golden yellow color in both images that can be easily distinguished from the various green to gray-green image tones of other associated vegetation and whitish tones of sparsely vegetated areas, bare soil, and water (Figure 2A only).

Leafy spurge had a similar image tone to that shown in Figures $2 \mathrm{~A}$ and $2 \mathrm{~B}$ at five other locations near Medora and seven sites near Lewistown and could be easily distinguished from other associated ecological ground variables. Differences in the yellow tonal responses of leafy spurge between the conventional color photographs and conventional color video images were attributed to the film emulsion layers versus video electronic coding. This has been demonstrated in previous research where conventional color photography and videography were compared for distinguishing common goldenweed [Isocoma coronopifolia (Gray) Greene \# IOCCO] infestations on Texas rangelands (9).

The GPS data at the bottom of the two video images (Figures 2A and 2B) of leafy spurge includes the bearing (direction), ground speed, altitude above sea level, date, north latitude, west longitude and time. The integration of the latitude-longitude coordinates with the video images is useful to the range manager or natural resource consultant to locate leafy spurge infestations over often remote rangeland areas.

Geo-referenced data can be readily entered into a GIS to map leafy spurge infestations over a region (14); however the video/GPS data obtained in this study were not integrated with a GIS. The video imagery also can serve as a permanent geographically located image database for each site. The accuracy of the GPS used in this study was approximately $\pm 100 \mathrm{~m}$ from the center coordinates of each video scene. A differential GPS can provide much better accuracy, but these systems are costly.

Page 9 of 15 
Figures $2 \mathrm{C}$ and $2 \mathrm{D}$ show the computer classifications of leafy spurge, shown as white areas, from the conventional color video images in Figures $2 \mathrm{~A}$ and $2 \mathrm{~B}$, respectively. Comparisons of both classifications to the respective video images showed that the computer identified most areas where leafy spurge was detectable. The computer classified $12 \%$ of both images as leafy spurge. Likewise, the computer estimated that the photo interpreter's overlay maps of Figures $2 \mathrm{~A}$ and $2 \mathrm{~B}$ had $12 \%$ and $13 \%$ leafy spurge, respectively.

To further compare the two classification techniques, the photo interpreter's overlay map for each location was superimposed over the computer classification map for each location. Although the percentages were essentially identical or very similar, there were some slight discrepancies in areas identified as leafy spurge in each map. Most of the differences were attributed to the photo interpreter's map where subjective boundary lines were drawn due to grading between leafy spurge and other plant species or soil. This was apparent in the photo interpreter's map where the outer perimeters of some leafy spurge populations did not agree with those of the computer classification. Other differences can be attributed to the computer classification technique that is based on discrete spectral classes, wherein a decision is made concerning each pixel (16).
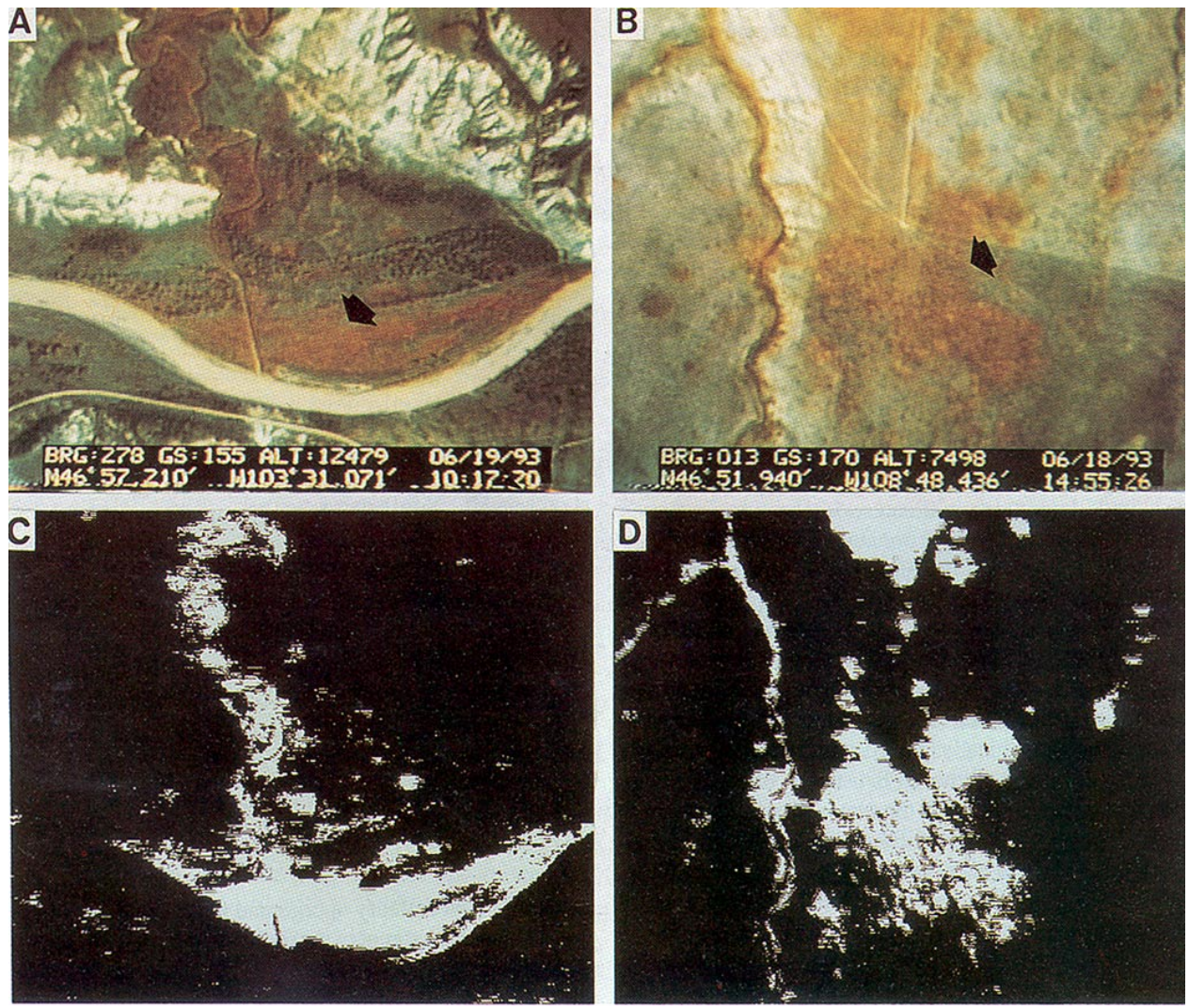

Figure 2 Conventional color video images of leafy spurge infestations near Medora, ND (A) and Lewistown, MT (B). The Medora image was obtained on June 19, 1993 at an altitude above ground level of $3000 \mathrm{~m}(1.7 \mathrm{~km}$ width of ground coverage) and has a horizontal ground pixel size of $3.2 \mathrm{~m}$. The Lewistown image was acquired on June 18,1993 at an altitude above ground level of $1200 \mathrm{~m}(0.7 \mathrm{~km}$ width of ground coverage $)$ and has a horizontal ground pixel size of $1.3 \mathrm{~m}$. Arrows on both prints point to the distinct golden-yellow image response of leafy spurge. The global positioning system data are shown at the bottom of each scene. Computer classifications of each video image are shown in prints $C$ and $D$. Areas classified as leafy spurge have a white code in each print. 
Ground surveys of the two areas indicated that the computer classification generally identified where most leafy spurge populations occurred. However, the Lewistown image (Figure 2B) and computer classification (Figure 2D) corresponded better to known locations of leafy spurge than the Medora image (Figure 2A) and classification (Figure 2C). The Lewistown image was acquired at $1200 \mathrm{~m}$ above ground level and had a horizontal ground pixel size of $1.3 \mathrm{~m}$, whereas the Medora image was taken at an altitude of $3000 \mathrm{~m}$ and had a ground pixel size of $3.2 \mathrm{~m}$. Thus, the coarser resolution of the higher altitude Medora image limited its ability to detect smaller stands or clumps of leafy spurge. Nonetheless, the Medora image and computer classification delineated the major stands and distribution of leafy spurge. Ground reconnaissance of the additional study sites at the two locations agreed with these findings. The computer classification results reported here are in agreement with those of other studies $(12,25)$ using similar procedures to discriminate weeds from other rangeland vegetation and agronomic crops in aerial photographic and videographic imagery.

Digital color value data. For site 1 (Medora), the digital color values of leafy spurge in the red and green bands were different from those of bare soil, mixed herbaceous species and mixed woody species (Table 2). However, the color value of leafy spurge in the

Table 2. Mean digital color values ${ }^{\mathrm{a}}$ for leafy spurge and associated vegetation and soil for the red, green, and blue bands from conventional color video imagery obtained from four sites in North Dakota and Montana.

\begin{tabular}{|c|c|c|c|c|}
\hline \multirow[b]{2}{*}{ Site } & \multirow{2}{*}{$\begin{array}{l}\text { Plant species, } \\
\text { mixture, or soil }\end{array}$} & \multicolumn{3}{|c|}{ Band $^{b}$} \\
\hline & & Red & Green & Blue \\
\hline \multirow{5}{*}{$\begin{array}{l}\text { Medora, ND } \\
\text { (Site 1) }\end{array}$} & & --------- & olor va & ------------- \\
\hline & Bare soil & $133 \mathrm{a}$ & $182 \mathrm{a}$ & $214 \mathrm{a}$ \\
\hline & Leafy spurge & $74 \mathrm{~b}$ & $104 \mathrm{~b}$ & $66 \mathrm{c}$ \\
\hline & Mixed herbaceous species & $54 \mathrm{c}$ & $84 \mathrm{c}$ & $90 \mathrm{~b}$ \\
\hline & Mixed woody species ${ }^{c}$ & $52 \mathrm{c}$ & $79 \mathrm{c}$ & $69 \mathrm{c}$ \\
\hline \multirow{3}{*}{$\begin{array}{l}\text { Medora, ND } \\
\text { (Site 2) }\end{array}$} & Bare soil & $156 a$ & $187 \mathrm{a}$ & $209 \mathrm{a}$ \\
\hline & Leafy spurge & $73 \mathrm{~b}$ & $100 \mathrm{~b}$ & $70 \mathrm{~b}$ \\
\hline & Mixed herbaceous species & $56 \mathrm{c}$ & $80 \mathrm{c}$ & $66 \mathrm{~b}$ \\
\hline \multirow{4}{*}{$\begin{array}{l}\text { Lewistown, MT } \\
\text { (Site 1) }\end{array}$} & Bare soil & $149 \mathrm{a}$ & $185 \mathrm{a}$ & $175 \mathrm{a}$ \\
\hline & $\begin{array}{l}\text { Mixed herbaceous species/ } \\
\text { sparsely vegetated }\end{array}$ & $99 \mathrm{~b}$ & $136 \mathrm{~b}$ & $139 \mathrm{~b}$ \\
\hline & Leafy spurge & $82 \mathrm{c}$ & $113 \mathrm{c}$ & $56 \mathrm{c}$ \\
\hline & Mixed woody species ${ }^{\mathrm{d}}$ & $59 \mathrm{~d}$ & $79 \mathrm{~d}$ & $46 \mathrm{~d}$ \\
\hline \multirow[t]{3}{*}{$\begin{array}{l}\text { Lewistown, MT } \\
\text { (Site 2) }\end{array}$} & $\begin{array}{l}\text { Mixed herbaceous species/ } \\
\text { sparsley vegetated }\end{array}$ & $98 \mathrm{a}$ & $134 \mathrm{a}$ & $127 \mathrm{a}$ \\
\hline & Leafy spurge & $82 \mathrm{~b}$ & $112 \mathrm{~b}$ & $57 \mathrm{~b}$ \\
\hline & Mixed woody species ${ }^{\mathrm{d}}$ & $53 \mathrm{c}$ & $79 \mathrm{c}$ & $35 \mathrm{c}$ \\
\hline \multicolumn{5}{|c|}{$\begin{array}{l}\text { a'Mean digital values represent the mean of ten } 1 \text { by } 1 \text { pixel subsamples, from images obtained on June } 19,1993 \text { at } \\
\text { Medora, ND, and June 18, } 1993 \text { at Lewistown, MT. } \\
\text { byalues within a column at each site/date followed by the same letter do not differ significantly at the } 0.05 \text { probability } \\
\text { level according to Duncan's multiple range test. } \\
\text { 'Mixed woody species included Rocky Mountain juniper, western snowberry, silver sagebrush, and American elm } \\
\text { (Ulmus americana L.). } \\
\text { dMixed woody species included Rocky Mountain juniper, western snowberry, Eastern cottonwood (Populus deltoides } \\
\text { Marsh.), and Ponderosa pine (Pinus ponderosa Dougl.). }\end{array}$} \\
\hline
\end{tabular}


blue band did not differ from that of mixed woody species. At Medora (site 2) leafy spurge color values in the red and green bands could be separated from those of bare soil and mixed herbaceous species, but in the blue band did not differ from that of mixed herbaceous species.

Leafy spurge digital color values at Lewistown (site 1) for all three bands were different from those of bare soil, mixed herbaceous species/sparsely vegetated areas, and mixed woody species (Table 2). Similarly, leafy spurge at Lewistown (site 2) in all three bands was separated from mixed herbaceous species/sparsely vegetated areas and mixed woody species.

These results suggest that all three spectral bands contribute to distinguishing leafy spurge in conventional color video imagery, but the red and green bands are probably most important. The separation of leafy spurge in the red band agrees with the ground reflectance measurements where leafy spurge could also be separated from associated plant species and soil in the visible red spectral wavelength (Table 1)

GIS leafy spurge map. Analysis of the digital park data derived from the 1:24,000 scale map indicated that the south unit of Theodore Roosevelt National Park covered approximately 18,676 ha of the North Dakota Badlands. This estimate compares favorably with the official park survey of 18,680 ha for the south unit.

Leafy spurge area estimates, derived from the aerial photography, accounted for 550 ha (or 3\%) of the park (Figure 3). Most of the infestation was restricted to drainage channels, creek bottoms, and river bottoms. Ground truth surveys of over 100 sites within the park selected from conventional color photographs resulted in correct identification of leafy spurge at all sites. Despite the fine spatial resolution $(0.3 \mathrm{~m})$ of the film, ground surveys showed that several sparse stands or clumps of leafy spurge with less than $25 \%$ canopy cover and single plants, some less than $30 \mathrm{~cm}$ in diameter, were generally not detectable in the photographs. In-canopy shadowing and shadows cast from other vegetation, as well as highly reflective soil background, contributed greatly to the inability to distinguish these plants (34). Other plants growing in mixtures of associated herbaceous species and under brush and trees could not be detected. Also, a few plants had limited bract formation, which prevented their detection in the photographs.

The GIS was a good base for incorporating the polygons of leafy spurge identified on aerial photographs. Distortions in the photography that were removed by using the GIS to register the data to the USGS orthophoto maps aided in accurately estimating the size of the spurge infestations. The joint use of GIS and remote sensing technology proved to be a powerful combination of tools, which provided previously unavailable information about the extent and spatial dynamics of leafy spurge within the park.

Our findings indicate that remote sensing techniques can be used successfully to distinguish leafy spurge populations on rangeland and other wildland areas when this weed produces distinct yellow-green bracts in early summer. Leafy spurge infestations could be delineated on both conventional color and color-infrared photographs $(1: 10,000$ to 


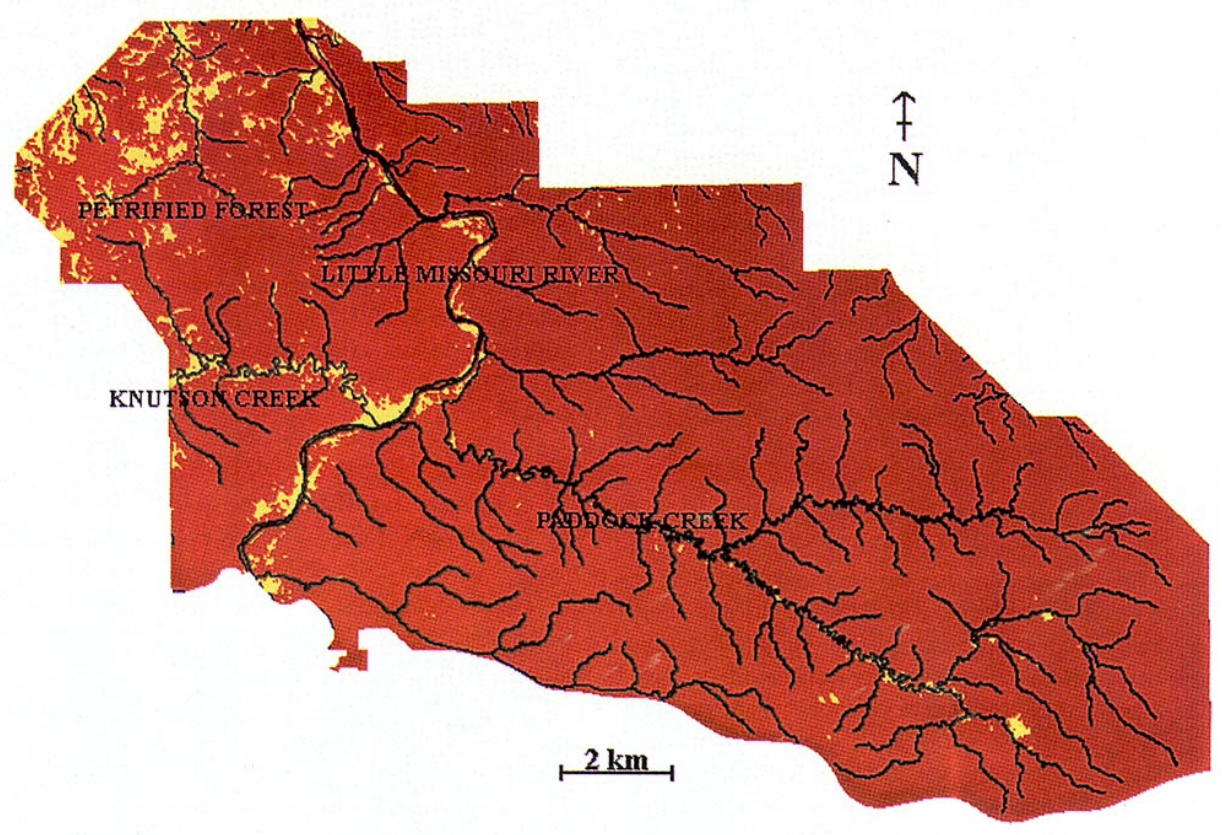

Figure 3. Map of leafy spurge infestations, shown in yellow, within Theodore Roosevelt National Park (orange area).

1:15,000 scales). Neither film type was superior to the other. Several sparse stands or clumps of leafy spurge with less than $25 \%$ canopy cover and single plants were generally not distinguishable in the photographs

Leafy spurge could also be distinguished on conventional color video imagery. However, the coarser resolution of video than that of photography limited its use for detecting small stands or clumps of leafy spurge. For example, in this study aerial video imagery obtained at an altitude above ground level of $3000 \mathrm{~m}$ had a resolution of $3.2 \mathrm{~m}$; whereas, aerial photography acquired at the same altitude had a resolution of $0.3 \mathrm{~m}$. Improved ground resolution can be obtained with video when the imagery is acquired at lower altitudes, but the ground area in each scene would be small and require more flying time.

The digitization and computer analyses of video images allowed for the quantification of leafy spurge. This technique can permit area estimates of leafy spurge populations. The video imagery was integrated with a GPS allowing for placement of latitudelongitude coordinates on each image. Conventional color photographs of Theodore Roosevelt National Park were digitized and integrated with a GIS to produce a map of leafy spurge populations within the park.

The joint use of remote sensing and GIS technologies can provide important information about the extent and spatial dynamics of leafy spurge over large areas. These data should be useful to natural resource managers who are interested in detecting, mapping, and monitoring the spread of noxious weeds over extensive and often inaccessible areas. 


\section{Literature cited}

1. Alley, H. P. and C. G. Messersmith. 1985. Chemical control of leafy spurge. p. 65-79 in A. K. Watson, ed. Leafy Spurge. Weed Sci. Soc. Am., Champaign, IL.

2. Anderson, G. L., J. H. Everitt, A. J. Richardson, and D. E. Escoban 1993. Using satellite data to map false broomweed (Ericameria austrotexana) infestations on South Texas rangelands. Weed Technol. $7: 865-871$.

3. Anderson, G. L., J. D. Hanson, and R. H. Haas. 1993. Evaluating LANDSAT thematic mapper derived vegetation indices for estimating above-ground biomass on semi-arid rangelands. Remote Sens. Environ. 45:165-175.

4. Anonymous. 1989. Biological control of leafy spurge. U.S. Dep. of Agric., Animal and Plant Health Inspection Serv. Progress Aid No. 1435. 11 p.

5. Bowers, S. A. and R. J. Hanks. 1965. Reflectance of radiant energy from soils. Soil Sci. 100: 130-138.

6. Dewey, S. A., K. P. Price, and D. Ramsey. 1991. Satellite remote sensing to predict potential distribution of Dyers woad (Isatis finctoria). Weed Technol. 5:479-484.

7. Eidenshink, J. C., R. H. Haas, D. M. Zokaites, D. O. Ohlen, and K. P. Gallo. 1988. Integration of remote sensing and GIS technology to monitor fire danger in the Northern Great Plains. U.S. Geol. Surv. Contract 14-08-000 1-22521. 13 p.

8. Elliston, R. and L. D. Miller. 1987. Mapping leafy spurge with color video and micro-computer image processing. p. 61-63 in Proc. West. Soc. Weed Sci. Vol. 40.

9. Everitt, J. H.. M. A. Alaniz, D. E. Escobar, and M. R. Davis. 1992. Using remote sensing to distinguish common (Isocoma coronopifolia) and Drummond goldenweed (Isocoma drummondii). Weed Sci. 40:621-628.

10. Everitt, J. H. and C. J. Deloach. 1990. Remote sensing of Chinese tamarisk (Tamarix chinensis) and associated vegetation. Weed Sci. 38:273-278.

11. Everitt, J. H., D. E. Escobar, A. H. Gerbermann, and M. A. Alaniz. 1988. Detecting saline soils with video imagery. Photogramm. Eng. Remote Sens. 54:1283-1287.

12. Everitt, J. H., D. E. Escobar, R. Villarreal, M. A. Alaniz, and M. R. Davis. 1993. Canopy light reflectance and remote sensing of shin oak (Quercus havardii) and associated vegetation. Weed Sci. 41:291297.

13. Everitt, J. H., A. J. Richardson, and P. R. Nixon. 1986. Canopy reflectance characteristics of succulent and non-succulent rangeland plant species. Photogramm. Eng. Remote Sens. 52:1891-1897.

14. Everitt, J. H., J. V. Richerson, M. A. Alaniz, D. E. Escobar, R. Villarreal, and M. R. Davis. 1994. Light reflectance characteristics and remote sensing of Big Bend loco (Astragalus mollissimus var. earlei) and Wooton loco (Astragalus wootonii). Weed Sci. 42:115-122.

15. Everitt, J. H., R. D. Pettit, and M. A. Alaniz. 1987. Remote sensing of broom snakeweed (Gutierrezia sarothrae) and spiny aster (Aster spinosus). Weed Sci. 35:295-302.

16. Everitt, J. H., A. J. Richardson, and C. L. Wiegand. 1981. Inventory of semi-arid rangelands in south Texas with Landsat data. p. 404-415 in Proc. Symp. Machine Processing Remotely Sensed Data. LARS, Purdue Univ., West Lafayette, IN.

17. Everitt, J. H. and R. Villarreal. 1987. Detecting huisache (Acacia farnesiana) and Mexican palo-verde (Parkisonia aculeata) by aerial photography. Weed Sci. 35:427-432.

18. Fay, P. K. 1991. Controlling leafy spurge with grazing animals. p. 193-199 in L. F. James, J. O. Evans, M. H. Ralphs, and R. D. Child, eds. Noxious Range Weeds. Western Press, Boulder, CO.

19. Gausman. H. W., R. M. Menges, D. E. Escobar, J. H. Everitt, and R. L. Bowen. 1977. Pubescence affects spectra and imagery of silverleaf sunflower (Helianthus argophyllus). Weed Sci. 25:437-440.

Page 14 of 15 
20. Graetz, R. D., R. P. Pech, M. R. Gentle, and J. F. O'Callaghan. 1983. The application of Landsat image data to rangeland assessment and monitoring: The development and demonstration of a land imagebased resource information system (LIBRIS). J. Arid Environ. 10:53-80.

21. Gylling, S. R. and W. E. Arnold. 1985. Efficacy and economics of leafy spurge (Euphorbia esula) control on pasture. Weed Sci. 33:381-385.

22. Lacey, C. A., P. K. Fay, R. G. Lym, C. G. Messersmith, B. Maxwell, and H. P. Alley, 1985. The distribution, biology and control of leafy spurge. Circ. 309. Coop. Ext. Serv., Montana State Univ., Bozeman, MT. 15 p.

23. Landgraf, B. K., P. K. Fay, and K. M. Havstad. 1984. Utilization of leafy spurge (Euphorbia esula) by sheep. Weed Sci. 32:348-352.

24. Lym, R. G. and C. G. Messersmith. 1985. Leafy spurge control with herbicides in North Dakota: 20year summary. J. Range Manage. 38:149-154.

25. Menges, R. M., P. R. Nixon, and A, J. Richardson. 1985. Light reflectance and remote sensing of weeds in agronomic and horticultural crops. Weed Sci. 33:569-581.

26. Myhre, R. J. 1987. Applications of aerial photography to several new and unusual vegetation pest problems. p. 49-53 in Proc. 10th Biennial Workshop on Color Aerial Photography in the Plant Sciences. Am. Soc. Photogramm. Remote Sens., Falls Church, VA.

27. Myhre, R. 1. 1992. Use of color airborne videography in the U.S. Forest Service. p. 145-152 in Proc. Resource Technol. 92 Symp. Am. Soc. Photogramm. Remote Sens., Bethesda, MD.

28. Noble, D. L., P. H. Dunn, and L. A. Andres. 1979. The leafy spurge problem. p. 8-15 in Proc. Leafy Spurge Symposium. North Dakota Coop. Ext. Serv., Fargo, ND.

29. Prather, T. S. and R. H. Callihan. 1993. Weed eradication using geographic information systems. Weed Technol. 7:265-269.

30. Quimby, P. C., W. L. Bruckart, C. J. Deloach, L. Knutson, and M. H. Ralphs. 1991. Biological control of rangeland weeds. p. 85-102 in L. F. James, J. O. Evans, M. H. Ralphs, and R. D. Child, eds. Noxious Range Weeds. Westview Press, Boulder, CO.

31. Rees, N. E. and N. R. Spencer. 1991. Biological control of leafy spurge. p. 182-192 in L. F James, J. O. Evans, M. H. Ralphs, and R. D. Child, eds. Noxious Range Weeds. Westview Press, Boulder, CO.

32. Richardson, A. J. 1981. Measurement of reflectance factors under daily and intermittent irradiance variations. Appl. Optics 20:1336-1340.

33. Richardson, A. J., K. R. Summy, M. R. Davis, A. Gomez, and D. W. Williams. 1993. The use of 1990 Tiger/Line Census files for monitoring the Rio Grande Valley cotton stalk destruction program. Proc. Appl. Advanced Inf. Technol. Symp. p. 231-239.

34. Richardson, A. J., C. L. Wiegand. H. W. Gausman, J. A. Cuellar, and A. H. Gerbermann. 1975. Plant, soil, and shadow reflectance components of row crops. Photogramm. Eng. Remote Sens. 41:14011407.

35. Skidmore. E. L., J. D. Dickerson, and H. Schimmelpfennig. 1975. Evaluating surface-soil water content by measuring reflectance. Soil Sci. Soc. Am. Proc. 39:238-242.

36. Steel, R.G.D. and J. H. Torrie. 1980. Principles and Procedures of Statistics. McGraw-Hill Book Co., New York. 481 p.

37. Stevens, O. A. 1963. Handbook of North Dakota Plants. Cushing-Malloy, Inc. Ann Arbor, MI. p. 197.

38. Tucker, C. J. 1979. Red and photographic infrared linear combinations for monitoring vegetation. Remote Sens. Environ. 8:127-150.

39. Tucker, C. J., W. H. Jones, W. A. Kley. and C. J. Sunstorm. 1980. The GSFC MARK-II three band hand-held radiometer. NASA Tech. Memo. 80641. 8 p.

40. Tueller, P. T. 1982. Remote sensing for range management. p. 125-140 in C. J. Johannsen and J. L. Sanders, eds. Remote Sensing for Resource Management. Soil Conserv. Soc. Am., Ankeny, IO. 